\title{
Influence of Beta-amulose Tri-iodide (Fertidyne) on Soil Fertility
}

\author{
George Samuels and F. González-Vélez ${ }^{1}$
}

INTRODUCTION

Fertidyne is the trade name of an organic iodine compound of very high molecular weight chemically known as beta-amulose tri-iodide. It is claimed by the distributor of this product that the addition of Fertidyne to the soil causes a stimulation of the metabolism of the soil bacteria, thereby inducing a marked increase in the rate of release of available nutrients in the soil ( $(3) .^{2}$

Iodine has been shown to be necessary for the maintenance of human beings in good health, but whether it is essential nutritionally for higher plants has not been definitely proven. Lewis and Powers (2) working with soils in Oregon, obtained some stimulatory effects on plant growth with iodine, but they were not consistent nor was the magnitude of response great enough to warrant hope of economic returns from iodine (potassium iodide) fertilization. Newton and Toth (4) failed to obtain responses in yields of tomatoes or buckwheat when using iodine on New Jersey soils.

Minto (3) in discussing the action of beta-amulose tri-iodide stated that it had a very low order of toxicity and that it maintained a constant ratio of free to bound iodine in the soil solution. Thus the concentration of freeiodine ions in solution does not exceed the tolerance of the soil bacteria, but as the cells extract iodine from solution in metabolic processes, the beta-amulose tri-iodide dissociates to maintain a continuous supply.

The effect of Fertidyne on soil bacteria has been demonstrated by Snell (3) in measuring carbon dioxide evolution from soil samples. The soil treated with Fertidyne had a 500-percent greater evolution of carbon dioxide. Measurements of soluble mineral nutrients extracted by acetic acid showed an increase in available nitrogen, phosphorus, and iron in the Fertidyne-treated soil.

The iodine content of Puerto Rican soils has not been determined nor have responses of these soils to iodine applications. Research was initiated to test the influence of beta-amulose tri-iodide ${ }^{3}$ (Fertidyne) as an iodine source on soils and crops of Puerto Rico. This paper reports the results of this work on sugarcane, tobacco, and pineapples.

${ }^{1}$ Agronomist and Research Assistant in Agronomy, respectively, Agronomy and Horticulture Department, Agricultural Experiment Station, University of Puerto Rico, Río Piedras, P.R.

2 Italic numbers in parentheses refer to Literature Cited. p. 182.

${ }^{3}$ For the sake of brevity, beta-amulose tri-iodide will henceforth be referred to as "Fertidyne," the name by which it is being sold commercially. 


\section{PROCEDURE}

In the three sugarcane trials begun in 1949 (table 1), the beta-amulose tri-iodide obtained was labeled "Fertidine," not "Fertidyne," and had no specifications as to concentration of active ingredients. The material was mixed with the fertilizer at the rate of 2 pounds of Fertidine per acre and applied to the furrow before the cane was planted. The plot size of the experiments was $1 / 100$ of an acre and each treatment was replicated nine

TaBle 1-Crop dala of sugarcane experiments with Fertidyne, 1949-61

\begin{tabular}{|c|c|c|c|c|c|}
\hline Location & Crop & $\left|\begin{array}{c}\text { Age of crop } \\
\text { (months) }\end{array}\right|$ & Year & Variety & Soil \\
\hline $\begin{array}{l}\text { Colonia Irurena, } \\
\text { Isabela }\end{array}$ & Plant cane & 12 & $1949-50$ & P.R. 902 & Coto clay \\
\hline $\begin{array}{l}\text { Luisa Farm, Central } \\
\text { Plazuela }\end{array}$ & do. & 16 & $1949-50$ & M. 336 & $\begin{array}{l}\text { Toa silty clay } \\
\text { loam }\end{array}$ \\
\hline Central Guánica & $\begin{array}{l}\text { Ratoon } \\
\text { Plant cane }\end{array}$ & $\begin{array}{l}12 \\
12\end{array}$ & $\begin{array}{l}1950-51 \\
1949-50\end{array}$ & P.O.J. 2878 & San Antón silty \\
\hline $\begin{array}{l}\text { Solis Farm, Río } \\
\text { Piedras }\end{array}$ & do. & 18 & $1957-59$ & P.R. 980 & $\begin{array}{l}\text { Vega Baja silty } \\
\text { clay }\end{array}$ \\
\hline & First ratoon & 12 & $1959-60$ & & \\
\hline & $\begin{array}{l}\text { Second } \\
\text { ratoon }\end{array}$ & 12 & $1960-61$ & & \\
\hline Miñi-Miñi, Loíza & Plant cane & 18 & $1959-61$ & P.R. 980 & $\begin{array}{l}\text { Palmas Altas } \\
\text { sandy clay } \\
\text { loam }\end{array}$ \\
\hline $\begin{array}{l}\text { Las Carolinas, } \mathrm{Fa}- \\
\text { jardo }\end{array}$ & do. & 18 & $1959-61$ & P.R. 980 & $\begin{array}{l}\text { Estación silty } \\
\text { loam }\end{array}$ \\
\hline $\begin{array}{l}\text { Santana, Camba- } \\
\text { lache }\end{array}$ & do. & 18 & $1959-61$ & P.R. 980 & $\begin{array}{l}\text { Espinosa sandy } \\
\text { clay }\end{array}$ \\
\hline $\begin{array}{l}\text { Felicidad, San Vi- } \\
\text { cente }\end{array}$ & do. & 18 & $1959-61$ & P.R. 980 & $\begin{array}{l}\text { Coloso loamy } \\
\text { sand }\end{array}$ \\
\hline
\end{tabular}

times for the Isabela and Guánica experiment and six times for the Plazuela experiment.

The Río Piedras experiment had a cycle of a plant cane and two ratoons. The beta-amulose tri-iodide used was the product Fertidyne, ${ }^{4}$ concentrate No. 2 with 25 -percent active ingredients. The material was used at the rate of 3 pounds per acre, dissolved in 100 gallons of water and applied with a knapsack sprayer over the furrow before the seed were planted. An additional 100 gallons of water was applied to wash the material down into the first 3 to 4 inches of the topsoil. The same rates of application were used for the ratoon crops, but the material was applied 1 to 2 weeks after cutting

4 This product was supplied by the Pilgrim Export Co., New York, N. Y. 
the cane when the trash had been aligned, but before the cane shoots were above the surface of the soil. The plot size consisted of four rows of cane with a total area of $1 / 100$ of an acre. Each treatment was replicated four times in a randomized block design.

The 1959-61 sugarcane experiments performed in cooperation with the Land Authority of Puerto Rico made use of paired plots of about 1 acre each, with and without the Fertidyne. The material used was the No. 1 concentrated (75-percent active ingredients) at the rate of 1 pound dissolved in 100 gallons of water. The Fertidyne solution was applied with a knapsack sprayer to the surface of the plowed field just before the forming of the furrows.

The tobacco experiment was made on a Mabi clay at the Gurabo Substation in 1958-59. The Fertidyne No. 2 concentrate was applied at the rate of 3 pounds per acre dissolved in 100 gallons of water. The material was sprayed over the surface of the soil, and the topsoil was reworked with a hoe to mix the Fertidyne well into the first 3 inches of the soil. The tobacco variety planted was Virginia 12, popularly grown in Puerto Rico for cigar fillers.

The pineapple experiments were located at Manatí and Río Piedras. For the Rio Piedras experiment the Red Spanish and Smooth Cayenne varieties were planted on a Vega Baja silty clay which had been previously fumigated with a nematocide. The Fertidyne No. 1 concentrate was applied at the rate of 1 pound per acre dissolved in 100 gallons of water. The material was sprayed on the soil and reworked with a hoe to mix it well into the first 3 inches of topsoil. The plots consisted of one row of pineapples planted 12 inches apart in the row with 18 plants per row. Each treatment was replicated four times.

The Manatí experiment was made on a Bayamón sandy clay on a ratoon srop of Red Spanish pineapple. The plots consisted of two rows with an area of about $1 / 181$ acre and replicated eight times.

\section{RESULTS WITH DIFFERENT CROPS}

\section{SUGARCANE}

The results of the eight sugarcane experiments are summarized in table 2. In this summary the yield of $96^{\circ}$ available sugar per acre for the regular fertilizer treatment was assigned a relative yield value of 100 percent. The relative yields from the other treatments were then calculated in proportion to the fertilizer treatment.

The general average of all experiments showed that an increase of 5 percent in relative yields was obtained with the use of Fertidyne. The increase due to Fertidyne averaged 6 percent for the plant crop, but this decreased 
to 4 percent for the first ratoon, and to 1 percent for the only second-ratoon crop recorded.

In the plant crop of the Rio Piedras experiment the relative yield of 124 percent for Fertidyne plus fertilizer was significant when compared to that

TABLE 2.-The effect of Fertidyne on the relative yields of $96^{\circ}$ available sugar, 1949-61

\begin{tabular}{|c|c|c|c|c|c|c|c|c|}
\hline \multirow{3}{*}{$\begin{array}{l}\text { Location of } \\
\text { experiment }\end{array}$} & \multicolumn{4}{|c|}{ Treatment in pounds per acre using - } & \multicolumn{4}{|c|}{ Relative yield of $96^{\circ}$ available sugar } \\
\hline & \multicolumn{3}{|c|}{ Fertilizer } & \multirow{2}{*}{ Fertidyne } & \multirow{2}{*}{ Plant crop } & \multirow{2}{*}{$\begin{array}{c}\text { First } \\
\text { ratoon }\end{array}$} & \multirow{2}{*}{$\begin{array}{l}\text { Second } \\
\text { ratoon }\end{array}$} & \multirow{2}{*}{$\begin{array}{c}\text { Average of } \\
\text { all crops }\end{array}$} \\
\hline & $\mathrm{N}$ & $\mathrm{P}_{2} \mathrm{O}_{6}$ & $\mathrm{~K}_{2} \mathrm{O}$ & & & & & \\
\hline \multirow[t]{2}{*}{ Isabela } & 300 & 300 & 300 & 0 & 100 & & & 100 \\
\hline & 300 & 300 & 300 & 2 & 108 & & & 108 \\
\hline \multirow[t]{2}{*}{ Plazuela } & 200 & 50 & 100 & 0 & 100 & 100 & & 100 \\
\hline & 200 & 50 & 100 & 2 & 106 & 104 & & 105 \\
\hline \multirow[t]{2}{*}{ Guánica } & 200 & 0 & 0 & 0 & 100 & & & 100 \\
\hline & 200 & 0 & 0 & 2 & 109 & & & 109 \\
\hline \multirow[t]{4}{*}{ Río Piedras } & 300 & 150 & 300 & 0 & 100 & 100 & 100 & 100 \\
\hline & 300 & 150 & 300 & 3 & 124 & 104 & 101 & 110 \\
\hline & 0 & 0 & 0 & 0 & 72 & & & - \\
\hline & 0 & 0 & 0 & 3 & 69 & & & - \\
\hline \multirow[t]{2}{*}{ Loiza } & 196 & 56 & 140 & 0 & 100 & & & 100 \\
\hline & 196 & 56 & 140 & 1 & 103 & & & 103 \\
\hline \multirow[t]{2}{*}{ Fajardo } & 196 & 56 & 140 & 0 & 100 & & & 100 \\
\hline & 196 & 56 & 140 & 1 & 85 & & & 85 \\
\hline \multirow[t]{2}{*}{ Cambalache } & 196 & 56 & 140 & 0 & 100 & & & 100 \\
\hline & 196 & 56 & 140 & 1 & 96 & & & 96 \\
\hline \multirow[t]{2}{*}{ San Vicente } & 200 & 0 & 0 & 0 & 100 & & & 100 \\
\hline & 200 & 0 & 0 & 1 & 118 & & & 118 \\
\hline \multirow[t]{2}{*}{ Average } & \multirow{2}{*}{\multicolumn{4}{|c|}{$\begin{array}{l}\text { Fertilizer } \\
\text { Fertilizer plus Fertidyne }\end{array}$}} & 100 & 100 & 100 & 100 \\
\hline & & & & & 106 & 104 & 101 & 104 \\
\hline \multicolumn{5}{|c|}{$\begin{array}{l}\text { Least significant difference needed between } \\
\text { treatment a verages for } 5 \text {-percent level }\end{array}$} & 10.0 & & & 11.2 \\
\hline
\end{tabular}

under the fertilizer alone (table 2). This increase, however, diminished with the succeeding ratoon crops.

In this same Rio Piedras experiment Fertidyne was applied to the soil without any fertilizer and compared to the check treatment which received 
no soil application of any kind. Fertidyne alone failed to increase yields over the check. There was a significant response to a commercial fertilizer as compared to the nonfertilized check. Fertidyne alone did not appear to have the ability to mobilize the nutrients in the soil to a great enough degree to obtain increases in yields comparable to the addition of a commercial

TABLE 3.-The influence of Fertidyne on cigar-filler tobacco yields on a Mabi clay at Gurabo

\begin{tabular}{|c|c|c|c|c|c|}
\hline \multicolumn{3}{|c|}{ Treatment in pounds per acre } & \multirow{2}{*}{$\begin{array}{l}\text { Yields of field } \\
\text { cured tobacco } \\
\text { per acre }\end{array}$} & \multirow{2}{*}{$\begin{array}{l}\text { Cash value of } \\
\text { crop per acre }\end{array}$} & \multirow{2}{*}{ Price per pound } \\
\hline N & $\mathrm{P}_{3} \mathrm{O}_{5}$ & $\mathrm{~K}_{2} \mathrm{O}$ & & & \\
\hline $\begin{array}{l}100 \\
100^{1}\end{array}$ & $\begin{array}{l}200 \\
200^{1}\end{array}$ & $\begin{array}{l}200 \\
200^{1}\end{array}$ & $\begin{array}{c}\text { Cwt. } \\
10.84 \\
11.28\end{array}$ & \begin{tabular}{r}
\multicolumn{1}{c}{ Dollars } \\
$\$ 445.06$ \\
450.93
\end{tabular} & $\begin{array}{c}\text { Cents } \\
41 \\
40\end{array}$ \\
\hline \multicolumn{3}{|c|}{$\begin{array}{l}\text { Least significant difference between } \\
\text { treatments: } \\
\text { 5-percent level }\end{array}$} & 0.67 & 88.16 & \\
\hline
\end{tabular}

1 Plus 3 lb. Fertidyne.

TaBle 4.-The effect of Ferlidyne on the yiclds of Red Spanish and Smooth Cayenne pineapples al Río Piedras, 1960-61

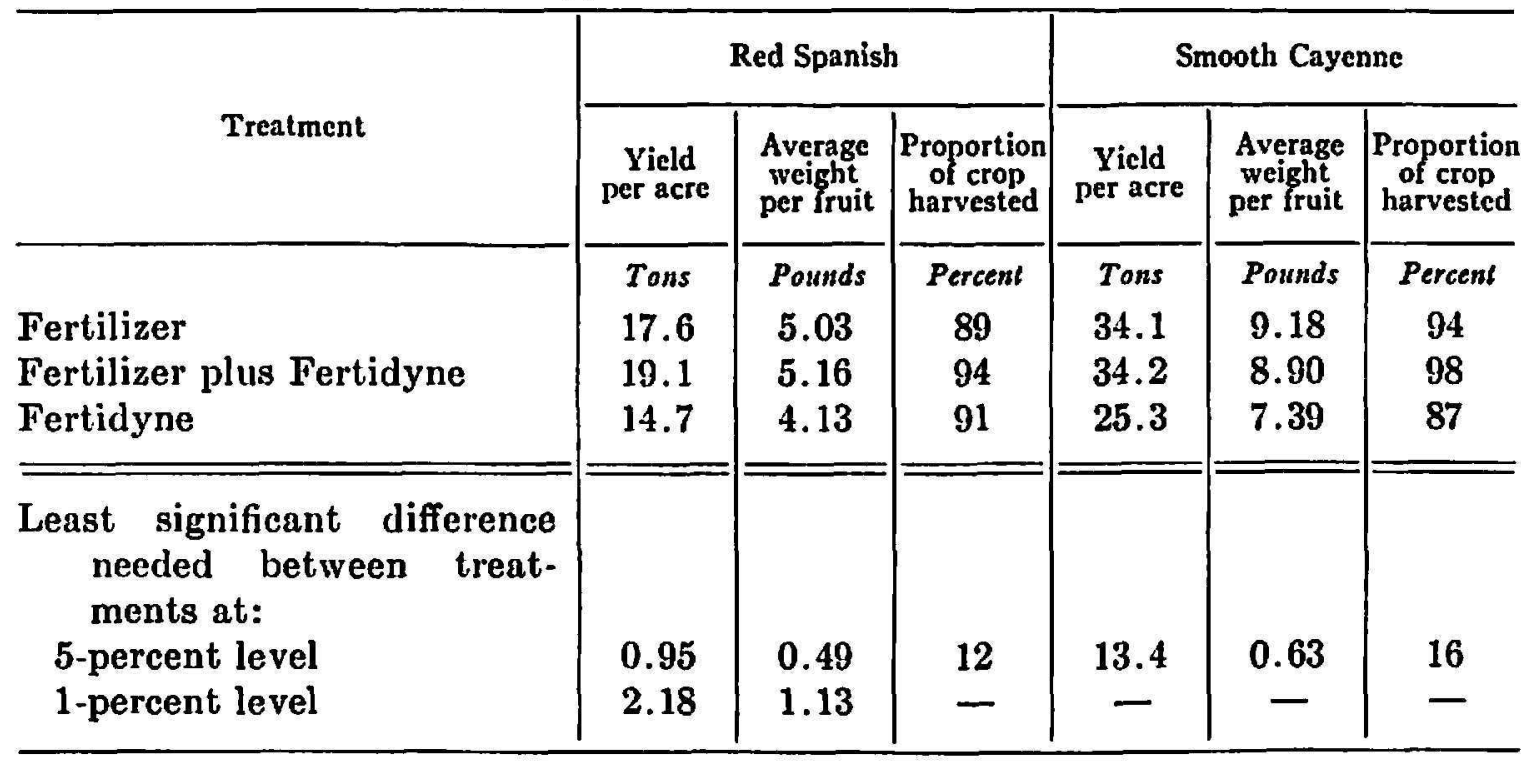

fertilizer. Yield responses were obtained with Fertidyne only when used in combination with adequate amounts of commercial fertilizer.

\section{TOBACCO}

The use of a tobacco fertilizer plus Fertidyne gave a nonsignificant increase of 0.44 hundredweight more tobacco than where fertilizer alone 
was applied (table 3). Fertidyne did not produce any significant increases in the cash value received for the crop.

\section{PINEAPPLES}

When Fertidyne was used with fertilizer in the Río Piedras experiment it gave an increase of 1.5 tons per acre of Red Spanish pineapples over the treatment with fertilizer alone (table 4). This gain was ascribed mostly to an increase in the proportion of the crop harvested, rather than to an increase in average weight of fruit. No significant increases were noted with the Smooth Cayenne variety.

Where Tertidyne was used alone there was a significant decrease in yield per acre from the treatment with fertilizer only for Red Spanish, and in average weight of fruit for the Smooth Cayenne.

TABLe 5.-The effect of Fertidyne on the yields of Red Spanish pineapples al Manali $1959-60$

\begin{tabular}{l|c|c|c}
\hline \multicolumn{1}{c|}{ Treatment } & Yicld per acre & $\begin{array}{c}\text { Average weight } \\
\text { of fruit }\end{array}$ & $\begin{array}{c}\text { Amount of crop } \\
\text { harvested }\end{array}$ \\
\cline { 2 - 3 } Check & Tons & Pounds & Percent \\
Fertilizer & 4.5 & 2.01 & 52 \\
Fertilizer plus Fertidyne & 13.5 & 2.90 & 86 \\
Fertidyne & 14.6 & 2.88 & 95 \\
\hline \hline Least significant differences needed between & 5.3 & 1.97 & 38 \\
$\quad$ treatments at: & & & \\
5-percent level & & & \\
1-percent level & 1.59 & 0.34 & 25 \\
\hline
\end{tabular}

At Manatí (table 5), Fertidyne failed to give significant yield increases when used alone or with fertilizers. As in the Río Piedras experiment, any gain in tonnage per acre was caused mostly by increases in the percentage of the crop harvested, and not in the average weight of each fruit.

\section{DISCUSSION}

The iodine content of the soils and crops of Puerto Rico is not known, nor has iodine been proved to be essential for high yields of agricultural crops. Yet if we are to assume that Fertidyne acts to supply iodine as micronutrient for plant growth, we see from the results of the experiments that there was no apparent iodine deficiency. Lewis and Powers, working in Oregon where simple goiter is endemic (2), and iodine contents of water and soils are low, obtained negative results from iodine fertilization. Simple goiter is not endemic to Puerto Rico. It might be justifiable to assume 
that iodine is constantly added to the soils of Puerto Rico because of the close proximity of the ocean to most of the Island, and the spray-laden breczes which sweep the Island.

It has been claimed that Fertidyne has the ability to stimulate soilbacteria metabolism which, in turn, causes the relcase of large quantities of available plant nutrients. Experiments with sugarcane (table 2, Río Piedras) and pineapple (table 5) indicate that Fertidyne used alone without fertilizer failed to mobilize sufficient plant nutrients to produce any appreciable increase in yield over the check where nothing was added to the soil. Inasmuch as these are long-growing crops of 1 year, there was time for the bacteria to have been stimulated to release the soil nutrients.

Some increases in yields were obtained when Fertidyne was used in experiments with sugarcane, pineapples, and tobacco. The results obtained were not always consistent nor significant, and were of a magnitude that possibly does not warrant adequate economic returns from the use of Fertidyne for the crops tested on the majority of the soils of Puerto Rico.

\section{SUMMARY}

Fertidyne (beta-amulose tri-iodide) was tested on many soils planted to sugarcane, tobacco, and pineapples to determine whether this material could increase yields. The results obtained were as follows:

1. Yields of sugar per acre, in general, were not significantly increased when Fertidyne was used with fertilizer as compared to yields under fertilizer alone.

2. Fertidyne alone did not increase yields of sugar significantly over the check treatment where nothing was added to the soil.

3. Fertidyne alone did not increase yields of sugar per acre when compared to the addition of fertilizer alone to the soil.

4. Yields of sugar per acre tended to be higher with Fertidyne for the plant crop than for the ratoons.

5. Neither tobacco yields nor quality were increased or improved when Fertidyne was used.

6. Pineapple yields, in general, did not increase when Fertidyne was applied, with or without fertilizer.

\section{RESUMEN}

Se probó el Fertydine (tri-yoduro de beta-amulosa) en suelos bajo cultivo de caña de azúcar, tabaco y piña para ver si su aplicación aumentaba el rendimiento de esas cosechas. Los resultados de este estudio fueron los siguientes:

1. Los rendimientos de azúcar por acre no aumentaron significativamente 
cuando se aplicó el Fertydine conjuntamente con el abono y se comparó su efecto con el de la aplicación de abono comercial solo.

2. El Fertydine, aplicado solo, no aumentó significativamente los rendimientos de azúcar sobre el tratamiento testigo cuando no se añadió otro fertilizante al suelo.

3. El Fertydine, aplicado solo, no aumentó los rendimientos de azúcar por acre, cuando se comparó su efecto con el de la aplicación al suelo de abono comercial solo.

4. Con la aplicación del Fertydine se observó una tendencia hacia aumentar los rendimientos del azúcar por acre más en la plantilla que en los retoños.

5. Ni la calidad ni los rendimientos del tabaco mejoraron con la aplicación del Fertydine.

6. En general, no hubo aumento en los rendimientos de la piña cuando se aplicó el Fertydine conjuntamente con el abono comercial, ni cuando se usó solo.

\section{LITERATURE CITED}

1. Davenport, C. G., and Love, A. G., Defects found in drafted men, Sci. Monthly 10 (5) $25,125-41,1920$.

2. Lewis, J. C., and Powers, W. L., Iodine in relation to plant nutrition, J. Agr. Res. 63 (11) 623-37, 1941.

3. Minto, W. L., A New Method of Increasing Soil Fertility without Fertilizer or Covercrops, I.B.C. Research Bul. No. 1, 1-19, I.B.C. Research Laboratories, Inc., New York, N.Y., 1959.

4. Newton, H. P., and Toth, S. J., Responses of crop plants to iodine and bromine, Soil Sci. 73 127-34, 1952. 